Article

\title{
Impact of In Vitro Gastrointestinal Digestion on the Bioaccessibility of Phytochemical Compounds from Eight Fruit Juices
}

\author{
Dasha Mihaylova $^{1} \mathbb{D}$, Ivelina Desseva ${ }^{2, * \mathbb{D}}$, Magdalena Stoyanova $^{2}$, Nadezhda Petkova $^{3} \mathbb{D}$, Margarita Terzyiska $^{4}$ \\ and Anna Lante $5, *$ (D)
}

1 Department of Biotechnology, Technological Faculty, University of Food Technologies, 4002 Plovdiv, Bulgaria; dashamihaylova@yahoo.com

2 Department of Analytical Chemistry and Physical Chemistry, Technological Faculty, University of Food Technologies, 4002 Plovdiv, Bulgaria; magdalena.stoianova@abv.bg

3 Department of Organic Chemistry and Inorganic Chemistry, Technological Faculty, University of Food Technologies, 4002 Plovdiv, Bulgaria; petkovanadejda@abv.bg

4 Department of Informatics and Statistics, University of Food Technologies, 4002 Plovdiv, Bulgaria; mterziyska@uft-plovdiv.bg

5 Department of Agronomy, Food, Natural Resources, Animals, and Environment-DAFNAE, Agripolis, University of Padova, 35020 Legnaro, Italy

* Correspondence: ivelina_hristova_vn@abv.bg (I.D.); anna.lante@unipd.it (A.L.); Tel.: +359-32-603-692 (I.D.)

Citation: Mihaylova, D.; Desseva, I.; Stoyanova, M.; Petkova, N.;

Terzyiska, M.; Lante, A. Impact of In Vitro Gastrointestinal Digestion on the Bioaccessibility of Phytochemical Compounds from Eight Fruit Juices. Molecules 2021, 26, 1187. https:// doi.org/10.3390/molecules26041187

Academic Editor: Maria Atanassova

Received: 15 January 2021

Accepted: 19 February 2021

Published: 23 February 2021

Publisher's Note: MDPI stays neutral with regard to jurisdictional claims in published maps and institutional affiliations.

Copyright: (C) 2021 by the authors. Licensee MDPI, Basel, Switzerland. This article is an open access article distributed under the terms and conditions of the Creative Commons Attribution (CC BY) license (https:/ / creativecommons.org/licenses/by/ $4.0 /)$.

\begin{abstract}
Fruits contain a number of useful substances including antioxidants. Their bio-accessibility after passing through the digestive tract is of primary importance when considering their benefits. In this respect, we investigated the effect of in vitro digestion on the phytochemicals of eight fruit juices. Freshly prepared juices from pomegranate, orange and grapefruit were used as well as commercially available juices from cherry, black grapes and aloe vera, blackberry and chokeberry, and two types of chokeberry and raspberries. Spectrophotometric and HPLC methods were used in order to analyse the sugar content, the total phenolic (TPC) and flavonoid contents (TFC), anthocyanins, phenolic acids and antioxidant activity. Principle component analysis was used to explain the differentiation among the types of fruit juice. Sugar recovery variation was between $4-41 \%$. The bio-accessibility of TPC ranged from $13.52-26.49 \%$ and of flavonoids between $24.25-67.00 \%$. The pomegranate juice and the juice of black grapes and aloe vera kept 58.12 and $50.36 \%$ of their initial anthocyanins content, while for the other samples less than $1.10 \%$ was established. As a result, a maximum of $30 \%$ remaining antioxidant activity was measured for some of the samples, but for most this was less than $10 \%$. In conclusion, fruit juices are a rich source of biologically active substances, but a more detailed analysis of food transformation during digestion is needed.
\end{abstract}

Keywords: bio-accessibility; in vitro digestion; antioxidants; phytochemicals; fruit juice

\section{Introduction}

Biological antioxidants have been defined as "compounds that protect biological systems against the potentially harmful effects of processes or reactions that cause extensive oxidations" [1]. Many food components are thought to possess antioxidant activity and are therefore considered to be beneficial for human health. Although a huge number of papers is focused on antioxidants research annually, there is still more to explore.

According to The World Health Organization [2] a daily consumption of at least $400 \mathrm{~g}$ of fruits and vegetables (equivalent to five daily servings) decreases the risk of several noncommunicable diseases: cardiovascular, chronic, and other diseases. The reason for this is their diverse composition. As plant derivatives, fruits and vegetables are rich in different secondary metabolites such as phenolic compounds, saponins, alkaloids, terpenoids, etc. [3]. The presence of these compounds is a prerequisite for health-promoting 
effects. Antioxidant, antibacterial, antifungal, antiviral, cholesterol-lowering, antithrombotic, or anti-inflammatory effects are among the most cited [3,4]. Accordingly, fruits and vegetables are very important in the human diet.

Food digestion is a complex process with many factors involved including individual particularities, resulting in expensive in vivo experiments and complicated data. In the past 10 years, much effort was put into establishing a reliable approach for omnibus human digestion simulation. Although this is a challenging task, several methods were proposed, with that of Brodkorb et al. [5] being the most comprehensive. Certainly, in vitro digestion models do not cover all the complexity of the process, but they are considered useful in predicting in vivo digestion impact [6]. Gastric digestion and intestinal digestion are expected to have different effects on phytochemicals, and thus change their antioxidant activity $[7,8]$. Previous studies have revealed that in some cases the content of phenolic substances and their antioxidant activity increased [9-11], while in others a decrease is reported $[12,13]$.

It has to be noted that various processing methods applied to food materials may have significant effects on their antioxidant potential and phytochemical bio-accessibility. For instance, the bio-accessibility and bioavailability of phenolic compounds could be affected by interaction with other present macromolecules such as proteins, carbohydrates and lipids [14]. These interactions could protect the phenolic compounds from oxidation during their passage through the gastrointestinal tract. On the other hand, phenol/protein interactions can lead to a loss of nutritional value due to protein precipitation and enzyme inactivation [15]. In this respect, more detailed phytochemical characteristics and more complete understanding of the digestion processes are needed [16].

So far, there are few reports on the effects of simulated digestion on the phenolic compounds and antioxidant activities of fruit juices [17]. Therefore, the aim of the present study is to evaluate the effect of in vitro digestion on the content and composition of sugars and phenolic substances of eight either freshly cold-pressed or commercially available fruit juices. The remaining antioxidant activity was also studied, thus revealing the real benefits for the human body of juice consumption. In this regard, spectrophotometric and HPLC (High-performance liquid chromatography) methods were used in order to evaluate the phytochemical profile and bio-accessibility.

\section{Results and Discussion}

Fruits and fruit juices are widely studied with respect to their biologically active substances and antioxidant capacity [18-20], but not many studies have focused on the transformations that occur during digestion $[10,13,21]$. The potential bioavailability of biologically active phytocompounds is important information linked directly to their health claims [22-25]. In this regard, physicochemical characteristics, phytochemical profile and the bio-accessibility of sugars and phytochemicals in eight fruit juices were assessed.

\subsection{Physicochemical Characteristics, Individual and Total Sugar Content of Fruit Juices Prior to In Vitro Digestion}

In this study eight fruit juices were subjected to in vitro gastrointestinal digestion. The individual and total phytochemical changes were studied, as well as the remaining antioxidant activity. Table 1 presents the results of the preliminary analyses of the tested juices. Naturally, fruit juices have a low $\mathrm{pH}$ [26]. This is mostly related to the presence of organic acids. The $\mathrm{pH}$ of the studied samples was between values 3 and 4, with grapefruit juice displaying the lowest (3.08) and pomegranate juice the highest value (3.80). The dry matter content varied from $5.1-16.67 \%$, and the highest value was established in sample $C$ (grapefruit juice) and the lowest in sample $\mathrm{H}$ (chokeberry and raspberry). 
Table 1. Physicochemical characteristics, individual and total sugar content of fruit juices prior to in vitro digestion **.

\begin{tabular}{|c|c|c|c|c|c|c|c|}
\hline $\begin{array}{c}\text { Sample/ } \\
\text { Assay }\end{array}$ & $\mathrm{pH}$ & Dry Content, \% & $\begin{array}{l}\text { Sucrose, } \\
\text { g/100 g }\end{array}$ & $\begin{array}{l}\text { Glucose, } \\
\text { g/100 g }\end{array}$ & $\begin{array}{c}\text { Fructose, } \\
\text { g/100 g }\end{array}$ & $\begin{array}{l}\text { Sorbitol, } \\
\text { g/100 g }\end{array}$ & $\begin{array}{c}\text { Total } \\
\text { Sugars, } \mathrm{g} / 100 \mathrm{~g}\end{array}$ \\
\hline $\mathrm{A}$ & 3.80 & 10.15 & $0.01 \pm 0.01^{\mathrm{e}}$ & $2.81 \pm 0.04^{\mathrm{c}}$ & $3.84 \pm 0.01^{b}$ & - & $6.64 \pm 0.06^{\mathrm{d}}$ \\
\hline B & 3.35 & 9.76 & $1.54 \pm 0.01^{b}$ & $1.84 \pm 0.01^{\mathrm{f}}$ & $1.88 \pm 0.02^{\mathrm{e}}$ & - & $5.17 \pm 0.02^{\mathrm{e}}$ \\
\hline $\mathrm{C}$ & 3.08 & 16.67 & $3.25 \pm 0.04^{\mathrm{a}}$ & $3.03 \pm 0.05^{b}$ & $3.10 \pm 0.03^{c}$ & - & $10.51 \pm 0.09^{a}$ \\
\hline $\mathrm{D}$ & 3.25 & 11.43 & $0.20 \pm 0.02^{d}$ & $2.60 \pm 0.04^{d}$ & $3.81 \pm 0.03^{b}$ & $0.49 \pm 0.01^{\mathrm{c}}$ & $7.11 \pm 0.03^{*, \mathrm{c}}$ \\
\hline E & 3.45 & 10.89 & $0.02 \pm 0.00^{\mathrm{e}}$ & $2.89 \pm 0.03^{c}$ & $1.78 \pm 0.02^{\mathrm{f}}$ & $0.58 \pm 0.01^{b}$ & $4.69 \pm 0.03 *, \mathrm{f}$ \\
\hline $\mathrm{F}$ & 3.40 & 13.33 & $0.42 \pm 0.02^{\mathrm{c}}$ & $4.00 \pm 0.02^{\mathrm{a}}$ & $4.85 \pm 0.01^{\mathrm{a}}$ & & $9.85 \pm 0.02^{b}$ \\
\hline G & 3.20 & 8.44 & $0.03 \pm 0.00^{\mathrm{e}}$ & $2.27 \pm 0.02^{\mathrm{e}}$ & $2.48 \pm 0.01^{\mathrm{d}}$ & - & $4.79 \pm 0.02^{\mathrm{f}}$ \\
\hline $\mathrm{H}$ & 3.48 & 5.12 & $0.04 \pm 0.01^{\mathrm{e}}$ & $0.80 \pm 0.01^{g}$ & $0.92 \pm 0.01 \mathrm{~g}$ & $0.90 \pm 0.02^{\mathrm{a}}$ & $2.69 \pm 0.01 *, \mathrm{~g}$ \\
\hline
\end{tabular}

${ }^{*}$ Data with sorbitol included. ${ }^{* *}$ The data is presented as the mean $(n=3) \pm$ S.D. Different letters within each column indicate significant differences between treatments according to Tukey's test at $p<0.05$.

Fruit juices are rich sources of sugars. In this regard, the individual content of sucrose, glucose, fructose and sorbitol was assessed by the HPLC-RID (refractive index detector) method, while the total sugar content was evaluated by the phenol-sulphuric method (Table 1). The results from HPLC-RID analysis indicated that the monosaccharides glucose and fructose dominated in all initial juices. Similar findings were reported earlier for carbonated beverages and fermented milks [27]. The total sugar content in the studied juices varied between 2.69 and $10.51 \mathrm{~g} / 100 \mathrm{~g}$ juice. The lowest value was detected in sample $\mathrm{H}$, which, however, is enriched with the sweetener sorbitol and steviol glycosides. Sorbitol was only detected in the samples that contained aronia juice (Sample D, E and $\mathrm{H}$ ), because it is inherent in this fruit [28]. In sample $\mathrm{H} 0.90 \mathrm{~g} / 100 \mathrm{~g}$ juice sorbitol were detected, while in samples D and $\mathrm{E}$ its content was 0.49 and $0.58 \mathrm{~g} / 100 \mathrm{~g}$ juice, respectively.

\subsection{Phytochemical Profile of Fruit Juices Prior to In Vitro Digestion}

The total phenolics, total flavonoids and total monomeric anthocyanins content of the studied fruit juices were evaluated and the results are presented in Table 2. The TPC varied between $0.81 \pm 0.01 \mathrm{mgGAE} / \mathrm{mL}$ for sample $\mathrm{G}$ and $15.56 \pm 0.06 \mathrm{mgGAE} / \mathrm{mL}$ for sample A. Tenfold lower content of extracts of citrus fruits was reported by Fejzić and Ćavar [29]. In the literature it is well demonstrated that chokeberry is one of the richest fruits in polyphenols [30]. In this regard, our results are in agreement with that of Denev et al. [31]. The lowest initial TFC was measured for sample G $(79.43 \pm 3.39 \mu \mathrm{gQE} / \mathrm{mL})$, while the highest was for sample C $(1667.71 \pm 23.66 \mu \mathrm{gQE} / \mathrm{mL})$. Similar TPC results are reported by Wern et al. [32], who studied fresh fruit juices, commercial fruit juices and fruit drinks. The total monomeric anthocyanins varied among the samples between 0 and $42.44 \pm 0.52 \mathrm{mg} / \mathrm{L}$. The highest content was detected in sample H. No anthocyanins were detected in samples $\mathrm{B}$ and $\mathrm{C}$ as they naturally do not possess such.

Table 2. Phytochemical profile of fruit juices prior to in vitro digestion *.

\begin{tabular}{cccc}
\hline Samples & $\begin{array}{c}\text { Total Phenolic } \\
\text { Contents (TPC), } \\
\text { mgGAE/mL }\end{array}$ & $\begin{array}{c}\text { Total Flavonoid } \\
\text { Contents (TFC), } \\
\mu \text { gQE/mL }\end{array}$ & $\begin{array}{c}\text { Total Monomeric } \\
\text { Anthocyanins, } \\
\text { mg/L }\end{array}$ \\
\hline A & $15.56 \pm 0.06^{\mathrm{a}}$ & $910.4 \pm 7.2^{\mathrm{b}}$ & $26.67 \pm 0.55^{\mathrm{b}}$ \\
$\mathrm{B}$ & $3.45 \pm 0.10^{\mathrm{e}}$ & $815.62 \pm 6.25^{\mathrm{c}}$ & $0^{\mathrm{f}}$ \\
C & $3.14 \pm 0.03^{\mathrm{e}}$ & $1667.71 \pm 23.66^{\mathrm{a}}$ & $0^{\mathrm{f}}$ \\
D & $4.13 \pm 0.06^{\mathrm{d}}$ & $627.60 \pm 3.61^{\mathrm{e}}$ & $3.28 \pm 0.05^{\mathrm{d}}$ \\
E & $5.71 \pm 0.08^{\mathrm{c}}$ & $548.44 \pm 34.80^{\mathrm{f}}$ & $3.35 \pm 0.11^{\mathrm{d}}$ \\
F & $1.14 \pm 0.02^{\mathrm{f}}$ & $459.90 \pm 11.84^{\mathrm{g}}$ & $1.81 \pm 0.03^{\mathrm{e}}$ \\
G & $0.81 \pm 0.01^{\mathrm{f}}$ & $79.43 \pm 3.39^{\mathrm{h}}$ & $19.56 \pm 0.53^{\mathrm{c}}$ \\
H & $7.45 \pm 0.33^{\mathrm{b}}$ & $713.03 \pm 9.15^{\mathrm{d}}$ & $42.44 \pm 0.98^{\mathrm{a}}$ \\
\hline
\end{tabular}

* The data is presented as the mean $(n=3) \pm$ S.D. Different letters within each column indicate significant differences between treatments according to Tukey's test at $p<0.05$. 
The content of phenolic acids evaluated by HPLC method was also studied and the results are presented in Table 3. Rosmarinic, cichoric and cinnamic acids were not detected in any of the samples and are not included in the table. Sample $\mathrm{C}$ displayed the highest content prior digestion for p-coumaric (12.23 $\pm 0.11 \mu \mathrm{g} / 100 \mathrm{~g}$ juice) and sinapic $(8.45 \pm 0.11 \mu \mathrm{g} / 100 \mathrm{~g}$ juice) acids and sample $\mathrm{D}$ for caffeic acid $(3.25 \pm 0.01 \mu \mathrm{g} / 100 \mathrm{~g}$ juice)

Table 3. Phenolic acids ( $\mu \mathrm{g} / 100 \mathrm{~g}$ juice) profile of fruit juices prior to in vitro digestion *

\begin{tabular}{|c|c|c|c|c|c|c|c|}
\hline Samples & Gallic Acid & $\begin{array}{l}\text { Protocatechuic } \\
\text { Acid }\end{array}$ & $\begin{array}{l}\text { Chlorogenic } \\
\text { Acid }\end{array}$ & Caffeic Acid & Ferulic Acid & $\begin{array}{c}p \text {-Coumaric } \\
\text { Acid }\end{array}$ & Sinapic Acid \\
\hline $\mathrm{A}$ & 0 & 0 & $1.25 \pm 0.07^{\mathrm{d}}$ & $1.54 \pm 0.05^{\mathrm{d}}$ & $<\mathrm{LOQ}$ & $0^{\mathrm{h}}$ & $2.31 \pm 0.08^{c}$ \\
\hline B & 0 & $<\mathrm{LOQ}$ & $1.63 \pm 0.03^{c}$ & $1.99 \pm 0.02^{c}$ & $<\mathrm{LOQ}$ & $3.92 \pm 0.08^{\mathrm{e}}$ & $2.22 \pm 0.06^{\mathrm{c}}$ \\
\hline $\mathrm{C}$ & 0 & 0 & $6.78 \pm 0.09^{a}$ & $0.75 \pm 0.01^{\mathrm{e}}$ & 0 & $12.23 \pm 0.11^{\mathrm{a}}$ & $8.45 \pm 0.11^{\mathrm{a}}$ \\
\hline $\mathrm{D}$ & $<\mathrm{LOQ}$ & 0 & $0 \mathrm{~g}$ & $3.25 \pm 0.01^{\mathrm{a}}$ & $<\mathrm{LOQ}$ & $11.46 \pm 0.11^{b}$ & $3.76 \pm 0.04^{b}$ \\
\hline E & $<$ LOQ & $<$ LOQ & $0 \mathrm{~g}$ & $1.61 \pm 0.08^{\mathrm{d}}$ & $<\mathrm{LOQ}$ & $4.24 \pm 0.05^{\mathrm{d}}$ & $0.83 \pm 0.01^{\mathrm{e}}$ \\
\hline F & 0 & $<\mathrm{LOQ}$ & $0.73 \pm 0.01^{\mathrm{e}}$ & $1.27 \pm 0.06^{\mathrm{e}}$ & $<\mathrm{LOQ}$ & $5.21 \pm 0.11^{\mathrm{c}}$ & $0.78 \pm 0.01^{\mathrm{f}}$ \\
\hline G & 0 & 0 & $3.53 \pm 0.109^{b}$ & $0.92 \pm 0.02^{g}$ & $<\mathrm{LOQ}$ & $3.15 \pm 0.05^{f}$ & $0.70 \pm 0.01^{\mathrm{g}}$ \\
\hline $\mathrm{H}$ & 0 & $<\mathrm{LOQ}$ & $0^{g}$ & $2.70 \pm 0.09^{b}$ & $<\mathrm{LOQ}$ & $2.12 \pm 0.02^{g}$ & $0.89 \pm 0.02^{d}$ \\
\hline
\end{tabular}

$<$ LOQ-below limit of quantification. ${ }^{*}$ The data is presented as the mean $(n=3) \pm$ S.D. Different letters within each column indicate significant differences between treatments according to Tukey's test at $p<0.05$.

\subsection{Bioaccessibility of Phytochemicals after In Vitro Digestion}

The physiological conditions, such as $\mathrm{pH}$, the presence of digestion enzymes and bile salts, significantly affect the bio-accessibility of food components [33] and their evaluation will contribute to understanding their biological significance within functional products $[34,35]$. Bio-accessibility of total sugars in foods significantly contributes to sugar intake [27]. Figure 1 presents the results of sugar availability after in vitro digestion of the studied samples. The recovery varied between $4-41 \%$ between samples. The lowest bio-accessibility was reported for sample H. Our observations were comparable with findings for other food products reported by Choi et al. [27]. According to their reports bio-accessibility of total sugars in carbonated beverages ranged from $54.6-69.4 \%$, and in fermented milks from $11.8-85.0 \%$. In the observation of patterns of sugar released from food matrices, both fructose and glucose are major compounds that are bioaccessible, implying that these are potentially bioavailable or susceptible to absorption through the gut barrier. The possible explanation for this common bio-accessibility of sugars from fruit juices are the complex food matrix and the presence of polyphenols and tannins, especially in red berries [36,37]. It has been reported previously that polyphenols may have an inhibitory effect on digestive enzymes such as $\alpha$-amylase and $\alpha$-glucosidase. Moreover, tannic acid and catechins decreased in vitro digestibility of various types of starch sources [38].

Simulated digestion had a significant negative impact on the total polyphenol content of the tested fruit juices (Table 4). The resulting bio-accessibility ranged between $13.52-26.49 \%$. The highest percentage was calculated for sample F, followed by sample D. It has been found by Bermudez-Soto et al. [39] that polyphenols are highly sensitive to mildly alkaline conditions such as in the intestine, where a proportion of the compounds is transformed into different structural forms with different chemical properties. In addition, during digestion phenolic compounds are susceptible to interaction with other released food components, such as iron, other minerals, dietary fibre or proteins that can lead to loss of phytochemicals [40]. 


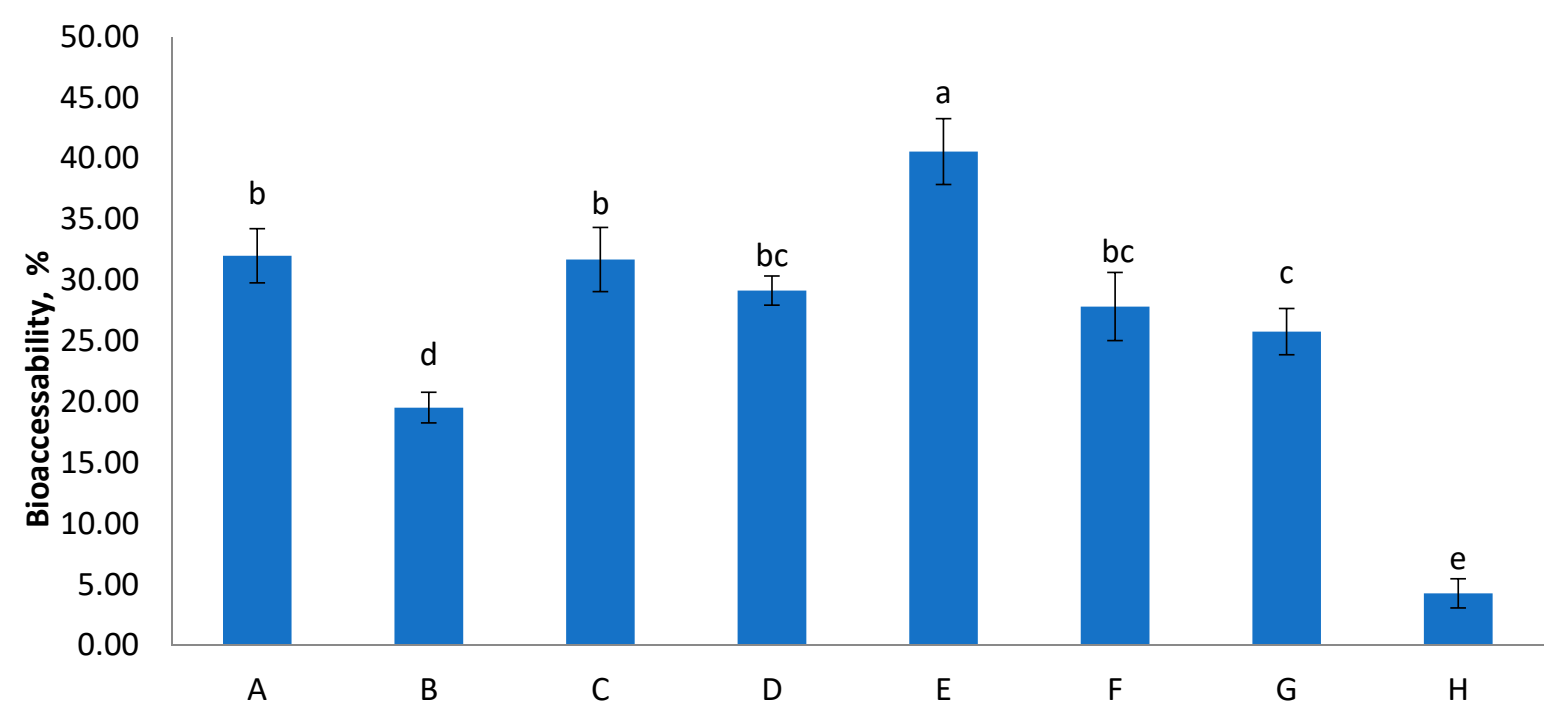

Figure 1. Bio-accessibility of total sugars from the digested juices (\%). Values are means \pm SEM, $n=3$ per treatment group. Means in a chart column without a common superscript letter differ $(p<0.05)$ as analysed by one-way ANOVA and the TUKEY test.

Table 4. Bio-accessibility (BA, \%) of phytochemicals after in vitro digestion *.

\begin{tabular}{|c|c|c|c|c|c|c|}
\hline \multirow{2}{*}{ Scheme } & \multicolumn{2}{|c|}{ TPC } & \multicolumn{2}{|c|}{ TFC } & \multicolumn{2}{|c|}{ Total Monomeric Anthocyanins } \\
\hline & mgGAE/mL & BA & $\mu g Q E / m L$ & BA & $\mathrm{mg} / \mathrm{L}$ & BA \\
\hline $\mathrm{A}$ & $15.56 \pm 0.06^{\mathrm{a}}$ & 19.74 & $910.40 \pm 7.2^{b}$ & 31.16 & $26.67 \pm 0.55^{b}$ & 58.12 \\
\hline $\mathrm{B}$ & $3.45 \pm 0.10^{\mathrm{e}}$ & 16.62 & $815.62 \pm 6.25^{c}$ & 34.64 & $0^{\mathrm{f}}$ & 0 \\
\hline $\mathrm{C}$ & $3.14 \pm 0.03^{\mathrm{e}}$ & 16.29 & $1667.71 \pm 23.66^{\mathrm{a}}$ & 31.56 & $0^{f}$ & 0 \\
\hline $\mathrm{D}$ & $4.13 \pm 0.06^{\mathrm{d}}$ & 26.20 & $627.60 \pm 3.61^{\mathrm{e}}$ & 24.25 & $3.28 \pm 0.05^{\mathrm{d}}$ & 0.93 \\
\hline $\mathrm{E}$ & $5.71 \pm 0.08^{c}$ & 13.52 & $548.44 \pm 34.80^{\mathrm{f}}$ & 26.98 & $3.35 \pm 0.11^{\mathrm{d}}$ & 0.89 \\
\hline $\mathrm{F}$ & $1.14 \pm 0.02^{\mathrm{f}}$ & 26.49 & $459.90 \pm 11.84 \mathrm{~g}$ & 67.00 & $1.81 \pm 0.03^{\mathrm{e}}$ & 1.11 \\
\hline G & $0.81 \pm 0.01^{\mathrm{f}}$ & 13.83 & $79.43 \pm 3.39 \mathrm{~h}$ & 35.53 & $19.56 \pm 0.53^{c}$ & 50.36 \\
\hline $\mathrm{H}$ & $7.45 \pm 0.33^{b}$ & 17.34 & $713.03 \pm 9.15^{\mathrm{d}}$ & 24.54 & $0^{\mathrm{f}}$ & 0 \\
\hline
\end{tabular}

* The data is presented as the mean $(n=3) \pm$ S.D. Different letters within each column indicate significant differences between treatments according to Tukey's test at $p<0.05$.

Flavonoids were less influenced by the digestion process resulting in bio-accessibility ranging between $24.25 \%$ (Sample D) and $67.00 \%$ (Sample F). Ovando-Martnez et al. [41] reported that the TFC of red chiltepin decreased after digestion in simulated gastrointestinal fluid, which was consistent with the present study.

The simulated digestion procedure included acidic $\mathrm{pH}$ (3.0) in the gastric phase, and subsequent increase to mildly alkaline $\mathrm{pH}(7.5)$ in the intestinal phase resulted in a significant decrease in the total monomeric anthocyanins present in the juices (Table 3). This transition leads to a reduction in the number of bio-accessible anthocyanins, as these pigments are highly unstable at intestinal $\mathrm{pH}$. However, relatively moderate bio-accessibility was detected for samples A and G, where the initial content had the highest values. The bio-accessibility in these samples was $58.12 \%$ and $50.36 \%$, respectively. For samples D, $\mathrm{E}, \mathrm{F}$, and $\mathrm{H}$ this was less than $1.10 \%$.

The bio-accessibility of the phenolic acids in the fruit juices was also affected by the digestion process and the results are presented in Table 5. Both loss and gain of phenolic acids were noted. For all the three freshly prepared juices, samples A, B, and C, chlorogenic acid was partly lost, resulting in bio-accessibility of $49.52 \%, 9.20 \%$, and $20.06 \%$, respectively. Meanwhile, in 4 of 5 commercial juices (samples D, E, and $\mathrm{H}$ ) this acid was not detected in the initial juices, but was released after the digestion procedure. Our results are in agreement with Bermúdez- Soto et al. [39] who reported increase of chlorogenic acid content after digestion of chokeberry, probably due to isomerisation 
reactions of neochlorogenic acid. While gallic acid was not quantifiable in sample D prior to digestion, $26.96 \pm 0.23 \mu \mathrm{g} / 100 \mathrm{~g}$ were detected afterwards. The same tendency was observed for protocatechuic acid in sample F, resulting in $20.70 \pm 1.01 \mu \mathrm{g} / 100 \mathrm{~g}$ after treatment. p-Coumaric acid was also liberated throughout digestion in samples $\mathrm{A}$ and $\mathrm{E}(2.60 \pm 0.08$ and $5.06 \pm 0.04 \mu \mathrm{g} / 100 \mathrm{~g}$, resp. $)$, and sinapic acid in $\mathrm{E}$ and $\mathrm{F}(2.00 \pm 0.03$, and $1.11 \pm 0.01 \mu \mathrm{g} / 100 \mathrm{~g}$, respectively). In this regard, other researchers considered the phenolic compounds as highly bio-accessible and potentially bioavailable with high stability. Seraglio et al. [42] reported a significantly increased bio-accessible fraction of phenolic compounds after simulated digestion when analyzing honey (1.73 times more). This may be due to the highly chemo-divergent nature of phenolic compounds, that include simple molecules on the one hand and big polymers on the other [43]. The latter are hydrolyzed during digestion as a sequence of the acidic environment of the stomach and of the slightly alkaline conditions of the intestine, as well as the action of the digestive enzymes [11]. These conditions lead to several changes in the phenol structure such as hydroxylation, methylation, iso-prenylation, dimerization and glycosylation, as well as formation of phenolic derivates by partial degradation of the combined forms due to losing the moieties between phenols and sugars [44].

Table 5. Bio-accessibility (BA, \%) of phenolic acids of fruit juices after in vitro digestion *.

\begin{tabular}{|c|c|c|c|c|c|c|c|c|c|c|c|c|c|c|}
\hline \multirow{2}{*}{ Samples } & \multicolumn{2}{|c|}{$\begin{array}{l}\text { Gallic } \\
\text { Acid }\end{array}$} & \multicolumn{2}{|c|}{ Protocatechuic Acid } & \multicolumn{2}{|c|}{$\begin{array}{l}\text { Chlorogenic } \\
\text { Acid }\end{array}$} & \multicolumn{2}{|c|}{$\begin{array}{l}\text { Caffeic } \\
\text { Acid }\end{array}$} & \multicolumn{2}{|c|}{$\begin{array}{l}\text { Ferulic } \\
\text { Acid }\end{array}$} & \multicolumn{2}{|c|}{$\begin{array}{c}p \text {-Coumaric } \\
\text { Acid }\end{array}$} & \multicolumn{2}{|c|}{$\begin{array}{c}\text { Sinapic } \\
\text { Acid }\end{array}$} \\
\hline & $\mu \mathrm{g} / 100 \mathrm{~g}$ & $\begin{array}{l}\text { Bio- } \\
\text { Accessibility } \\
\text { (BA) }\end{array}$ & $\mu \mathrm{g} / 100 \mathrm{~g}$ & BA & $\mu \mathrm{g} / 100 \mathrm{~g}$ & BA & $\mu \mathrm{g} / 100 \mathrm{~g}$ & BA & $\mu \mathrm{g} / 100 \mathrm{~g}$ & BA & $\mu \mathrm{g} / 100 \mathrm{~g}$ & BA & $\mu \mathrm{g} / 100 \mathrm{~g}$ & BA \\
\hline A & $0^{\mathrm{b}}$ & - & $0^{\mathrm{b}}$ & - & $0.62 \pm 0.03 \mathrm{e}$ & 49.52 & $0.20 \pm 0.01 \mathrm{c}$ & 13.02 & 0 & - & $2.60 \pm 0.08^{c}$ & $>100$ & ${ }_{0} \mathrm{f}$ & - \\
\hline B & $0^{b}$ & - & $0^{\mathrm{b}}$ & - & $0.15 \pm 0.01 \mathrm{f}$ & 9.20 & ${ }_{0} \mathrm{e}$ & - & 0 & - & $1.56 \pm 0.08 \mathrm{f}$ & 39.80 & $0.67 \pm 0.01^{c}$ & 30.18 \\
\hline C & $0^{\mathrm{b}}$ & - & $0^{\mathrm{b}}$ & - & $1.36 \pm 0.02 \mathrm{~d}$ & 20.06 & ${ }_{0} \mathrm{e}$ & - & $<\mathrm{LOQ}$ & NB & $2.54 \pm 0.02 \mathrm{~d}$ & 20.77 & $2.67 \pm 0.02 \mathrm{a}$ & 31.60 \\
\hline D & $26.96 \pm 0.23 \mathrm{a}$ & $>100$ & $0^{\mathrm{b}}$ & - & $11.98 \pm 0.55^{b}$ & $>100$ & $0.23 \pm 0.01^{c}$ & 6.99 & 0 & - & $4.07 \pm 0.03 \mathrm{~b}$ & 35.54 & $1.42 \pm 0.02 \mathrm{~d}$ & 37.69 \\
\hline E & $0^{\mathrm{b}}$ & - & $0^{\mathrm{b}}$ & - & $8.80 \pm 0.23^{C}$ & $>100$ & $0.32 \pm 0.02 \mathrm{~b}$ & 19.78 & 0 & - & $5.06 \pm 0.04 \mathrm{a}$ & $>100$ & $2.00 \pm 0.03 \mathrm{~b}$ & $>100$ \\
\hline F & $0^{\mathrm{b}}$ & - & $20.70 \pm 1.01 \mathrm{a}$ & $>100$ & $9.37 \pm 0.21^{c}$ & $>100$ & $0.99 \pm 0.02^{a}$ & 77.95 & 0 & - & $2.64 \pm 0.02^{c}$ & 50.67 & $1.11 \pm 0.01 \mathrm{e}$ & $>100$ \\
\hline G & $0^{\mathrm{b}}$ & - & $0^{\mathrm{b}}$ & - & $<\mathrm{LOQ}$ & NB & ${ }_{0} \mathrm{e}$ & - & 0 & - & $0 \mathrm{~g}$ & - & ${ }_{0} \mathrm{f}$ & - \\
\hline $\mathrm{H}$ & $0^{\mathrm{b}}$ & - & $0^{\mathrm{b}}$ & - & $67.44 \pm 1.11^{\mathrm{a}}$ & $>100$ & $0.15 \pm 0.01 \mathrm{~d}$ & 5.69 & 0 & - & $1.71 \pm 0.02 \mathrm{e}$ & 80.86 & ${ }_{0} \mathrm{f}$ & - \\
\hline
\end{tabular}

* The data is presented as the mean $(n=3) \pm$ S.D. Different letters within each column indicate significant differences between treatments according to Tukey's test at $p<0.05$.

\subsection{Antioxidant Capacity before and after In Vitro Gastrointestinal Digestion of Fruit Juices}

The presence of phytochemicals in the tested fruit juices predetermines their antioxidant activity (AOA). In this regard four generally recognized methods were used (Figure 2). The information they provide is complementary, as these methods differ in their mode of action. Ferric-Reducing Antioxidant Power (FRAP) and Cupric Ion Reducing Antioxidant Capacity (CUPRAC) assays evaluate the reducing potential of the sample, whereas 2,2diphenyl-1-picrylhydrazyl (DPPH) and 2,2'-azino-bis(3-ethylbenzothiazoline-6-sulfonic acid (ABTS) assays evaluate its anti-radical scavenging activity [45]. While it may be useful to know the antioxidant capacity of fruit juices before digestion for comparative purposes, this is not a true reflection of their potential health effects. A more realistic view is gained from the antioxidant capacity after the fruit juices have undergone a simulated digestion procedure, when the antioxidants potentially available for absorption can be measured. In our study, the highest initial activity was established for samples $\mathrm{A}$ and $\mathrm{H}$. For these two samples as well as for sample $\mathrm{D}$ and $\mathrm{E}$ the reducing potential was higher compared to the anti-radical scavenging activity. The results were in accordance with the highest TPC of these juices indicating the main contribution of the polyphenolic compounds to the antioxidant potential of the samples. Ryan and Prescot [46] also determined that pomegranate juice possessed the highest antioxidant activity pre- and post-digestion compared to other types of juice that were analyzed (orange, apple, pineapple, grapefruit, red grape, cranberry). It seems that the TFC did not contribute to the overall AOA of the samples. Although sample $C$ displayed the highest TFC prior to digestion, the initial antioxidant potential of this sample was negligible and almost nil after digestion. The loss of phytochemicals reflects the remaining antioxidant capacity after digestion [11]. This trend was observed for all the samples by all the methods used. A maximum of 30\% remaining 
AOA was measured for some of the samples. However, for the majority of digested juices less than $10 \%$ was detected. Our results are consistent with previous research studies on fruit juices subjected to digestion, where significant decreases in antioxidant capacity were demonstrated $[10,13,39,47]$.

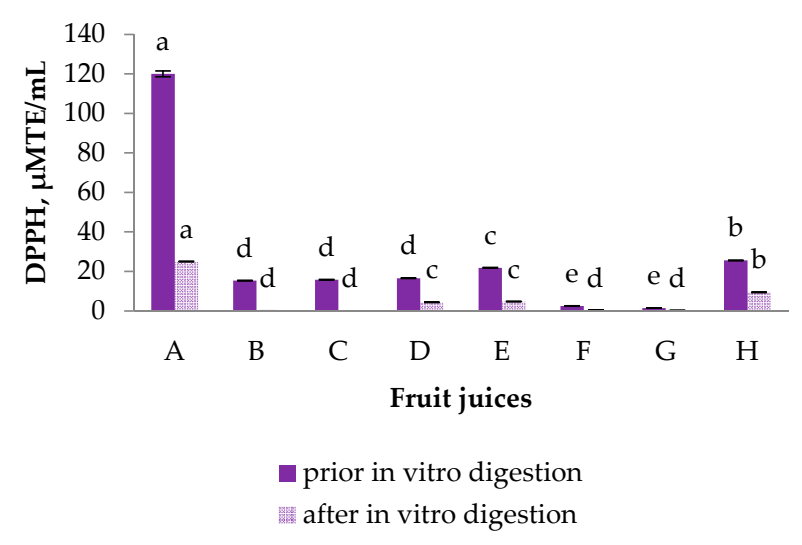

(A)

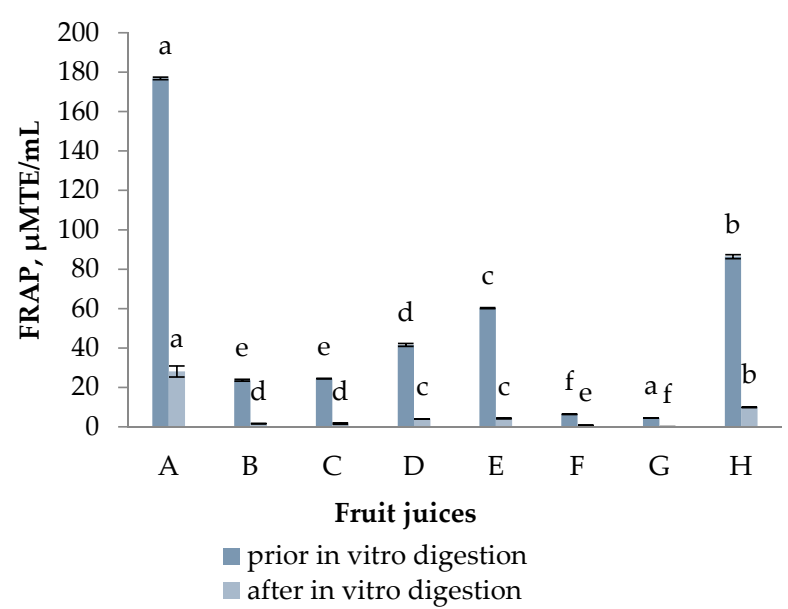

(C)

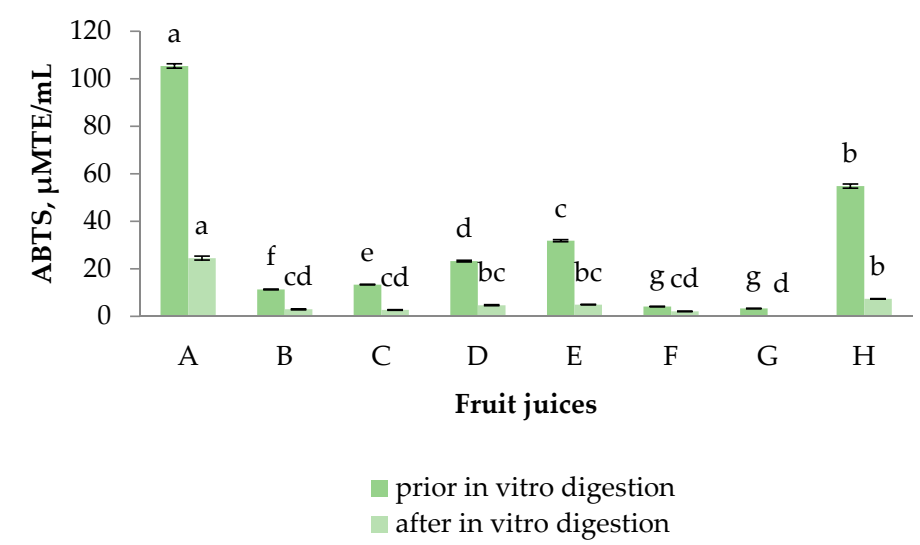

(B)

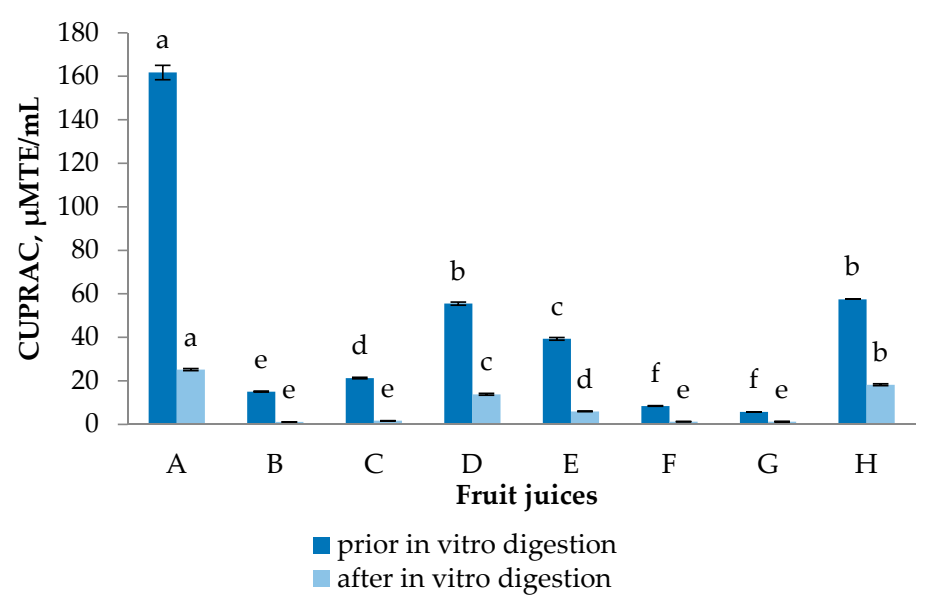

(D)

Figure 2. Antioxidant capacity of selected fruit juices before and after in vitro gastrointestinal digestion by (A) 2,2-diphenyl1-picrylhydrazyl (DPPH) radical scavenging activity, (B) 2,2'-azino-bis(3-ethylbenzothiazoline-6-sulfonic acid (ABTS) radical scavenging activity, (C) Ferric-Reducing Antioxidant Power (FRAP) and (D) Cupric Ion Reducing Antioxidant Capacity (CUPRAC) assays. The data is presented as the mean $(n=3) \pm$ S.D. Different letters within chart columns indicate significant differences between treatments according to Tukey's test at $p<0.05$.

\subsection{Principal Component Analysis}

Principal component analysis (PCA) allows summarizing of information in large data tables by means of a smaller set of factors in such a way as to be more easily visualized and analyzed. Another kind of graphic closely associated with PCA is biplot. This shows the variances and correlations of the variables, as well as the distances among the units. Biplot consists of lines and dots. Lines are used to reflect the variables of the dataset, and dots are used to show the observations.

In the current study, PCA is used to explain the differentiation among the different types of fruit juice by a small number of linear combinations of the different variables responsible for most of the variability in the data. The PCA analysis was performed under the following conditions: the Kaiser-Meyer-Olkin Measure of Sampling Adequacy statistic is 0.741 , which exceeds the recommended value of 0.60 . Bartlett's test for sphericity was statistically significant $(p<0.001)$. Here, the studied dataset are eight different types of 
juice, and the variables are their chemical characteristics: TPC, TFC, Anthocyanins and AOA. The biplot graphics based on PCA for the most important factors (F1 and F2) for prior to digestion and post-digestion stages are given in Figures 3 and 4, respectively. It can be seen from Figure 3 that TPC contributes significantly towards the AOA of most of the juices. The percentage of variability represented by the first two factors is high $(90.67 \%)$ in the case of prior digestion. The first factor (F1) explains $71.25 \%$ of the total variance of the significant parameters TFC and AOA, whereas F2 explains $19.42 \%$ of the total variance with significant parameters TPC and Anthocyanins in the phase prior in vitro digestion. From the PCA analysis, the pomegranate juice (sample A) was found to be more associated with antioxidant activity and phenolic compound content prior to the digestion phase.

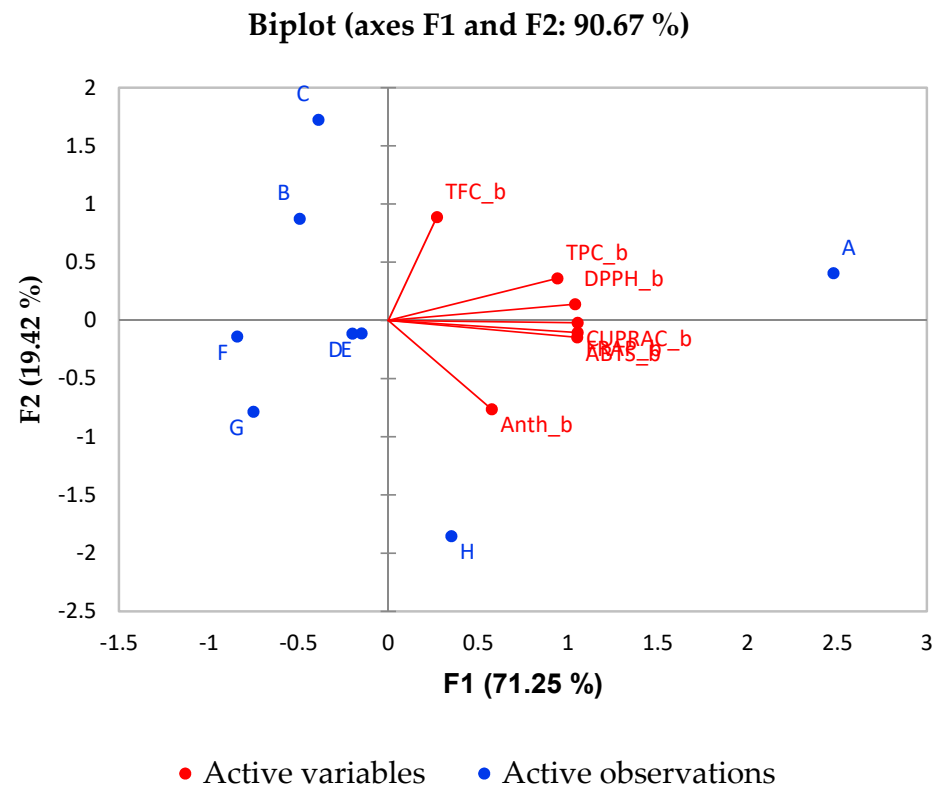

Figure 3. Biplot of for PCA analysis of fruit juices.

Biplot (axes F1 and F2: $89.94 \%$ )

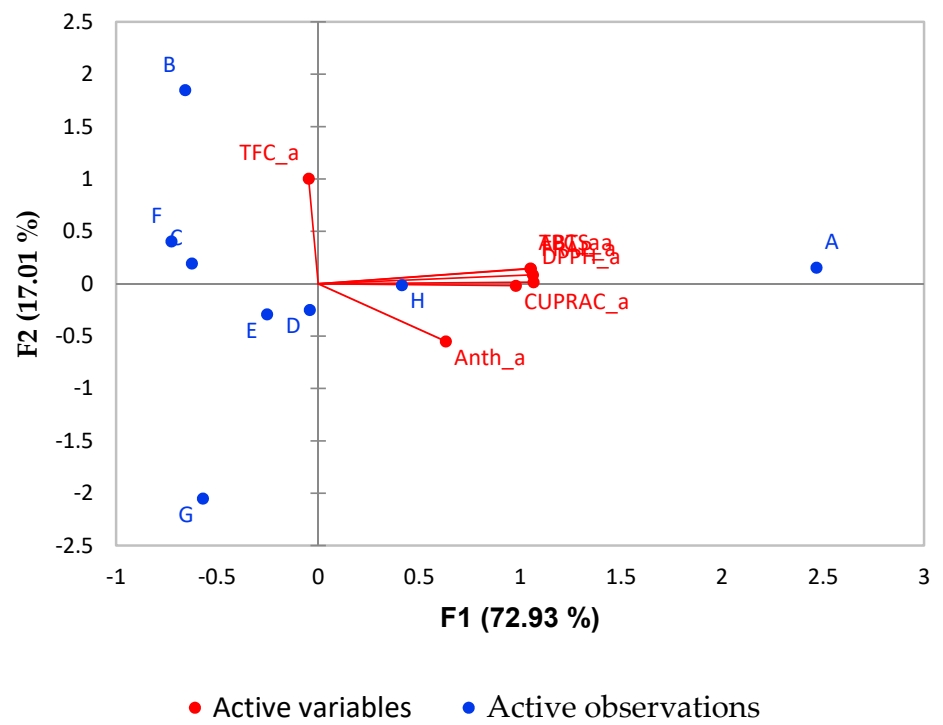

Figure 4. Biplot for PCA analysis of in vitro digested juices.

It is evident from Figure 4 that the trend is almost the same for the in vitro postdigestion phase. The percentage of variability represented by the first two factors is high 
$(89.94 \%)$ in this case. The first factor (F1) explains $72.93 \%$ of the total variance of significant parameters TPC and AOA of the different juices while F2 explains 19.01\% of the total variance of significant parameter TFC. Again, sample A (pomegranate juice) is associated with the best antioxidant activity and phenolic compounds content. Interestingly, in sample $\mathrm{H}$ better correlation with the AOA and phenolic compounds is observed after digestion compared to prior in vitro digestion.

\section{Materials and Methods}

\subsection{Chemicals and Reagents}

All reagents used in this study were of analytical grade and purchased from Merck Chemicals (Darmstadt, Germany) and Sigma-Aldrich (St. Louis, MO, USA).

\subsection{Fruit Juices Samples}

The fruit juices that were used in this study were either purchased from a local fresh fruit juice shop (three samples) where they were freshly cold-pressed on a slow-turn juicer or purchased from a local shop as randomly chosen commercial products (five samples). The cold pressed juices were obtained from pomegranate (Punica granatum L., sample A), orange (Citrus $\times$ sinensis (L.) Osbeck, sample B) and grapefruit (Citrus $\times$ paradisi Macfad, sample C). The commercial products on the other hand were mixtures as follows: juice of raspberries and chokeberry (3:1, min 40\% fruit content, sample D), juice of blackberry and chokeberry (3:1, min 40\% fruit content, sample E), juice of cherry (min $40 \%$ fruit content, sample F), juice of black grapes and aloe vera juice and chunks (10 and 12\%, respectively, sample G) and juice of chokeberry and raspberries (36 and 4\%, respectively, with natural sweetener steviol glycosides, sample H). All juices were then immediately subjected to analysis. Three independent samples were made and tested from the same material and the results are presented as mean. Simulated gastric fluid (SGF) and simulated intestinal fluid (SIF) were prepared as described by Brodkorb et al. [5].

\subsection{In Vitro Gastro-Intestinal (GI) Digestion}

The assay was performed according to the procedures described by Brodkorb et al. [5] with minor modifications. Only the gastric and intestinal phase were included.

\subsubsection{Gastric Phase}

Fruit juice $(5 \mathrm{~mL})$ was mixed with $3.62 \mathrm{~mL}$ of a porcine pepsin stock solution (pepsin from porcine gastric mucosa, P7000, Sigma-Aldrich, St. Louis, MO, USA; 5520 U/mL made up in SGF electrolyte stock solution), $2.5 \mu \mathrm{L}$ of $0.3 \mathrm{M} \mathrm{CaCl}_{2}$ and $132 \mu \mathrm{L}$ of phospholipids $(0.17 \mathrm{mM}$ in the final digestion mixture). The $\mathrm{pH}$ of the mixture was corrected with $1 \mathrm{M} \mathrm{HCl}$ to the value of 3.0 and the volume of the mixture was made up to $10 \mathrm{~mL}$ with distilled water. The mixture was then incubated at $37^{\circ} \mathrm{C}$ with constant shaking in a shaking water bath for $2 \mathrm{~h}$. The $\mathrm{pH}$ was regularly checked and re-adjusted with $1 \mathrm{M} \mathrm{HCl}$ when needed.

\subsubsection{Intestinal Phase}

Gastric chyme $(10 \mathrm{~mL})$ was mixed with $8 \mathrm{~mL}$ of a pancreatin solution (pancreatin from porcine pancreas, P1750, Sigma-Aldrich, St. Louis, MO, USA; 1.72 U/mL made up in SIF electrolyte stock solution based on trypsin activity), $1.9 \mathrm{~mL}$ of fresh bile extract (160 mM fresh bile salts in final mixture, Sigma-Aldrich, St. Louis, MO, USA), $20 \mu \mathrm{L}$ of $0.3 \mathrm{M} \mathrm{CaCl}_{2}, 1 \mathrm{M} \mathrm{NaOH}$ to reach $\mathrm{pH} 7.5$, and water to $20 \mathrm{~mL}$ total volume. The mixture was then incubated at $37^{\circ} \mathrm{C}$ in a shaking water bath for $2 \mathrm{~h}$. The $\mathrm{pH}$ was regularly checked and re-adjusted with $1 \mathrm{M} \mathrm{NaOH}$ during the process if needed.

For the blank sample, water was used instead of juice. The values obtained for blanks were subtracted from the sample values for each analysis. The digestion sample was then centrifuged and stored at $-20^{\circ} \mathrm{C}$ till further analysis, but no longer than for 7 days. 


\subsection{Moisture Content}

Total moisture content of the samples was determined in moisture analyzer balance (Radwag PMC 50/NH, Radom, Poland). The sample was placed in a dish and dried to constant mass at $105^{\circ} \mathrm{C}$.

\subsection{Total Polyphenol Content Analysis (TPC)}

The total polyphenol content was analyzed using the Folin-Ciocalteu method of Kujala et al. [48] with some modifications. Each sample $(1 \mathrm{~mL})$ was mixed with $5 \mathrm{~mL}$ of Folin-Ciocalteu's phenol reagent and $4 \mathrm{~mL}$ of $7.5 \% \mathrm{Na}_{2} \mathrm{CO}_{3}$. The mixture was vortexed for $10 \mathrm{~s}$ and incubated for $5 \mathrm{~min}$ at $50^{\circ} \mathrm{C}$. The absorbance was then measured at $765 \mathrm{~nm}$ against a blank consisting of solvent instead of sample, using SPECTROstar Nano Microplate Reader (BMG LABTECH, Ortenberg, Germany). The TPC in the extracts was expressed as $\mathrm{mg}$ gallic acid equivalent (GAE) per $\mathrm{mL}$ juice. The linear range for gallic acid standard was $5-100 \mathrm{mg} / \mathrm{L}\left(R^{2}=0.9965\right)$.

\subsection{Total Flavonoid Content (TFC)}

The total flavonoid content was evaluated according to the method described by Kivrak et al. [49]. An aliquot of $0.5 \mathrm{~mL}$ of native or digested juice samples was added to $0.1 \mathrm{~mL}$ of $10 \% \mathrm{Al}\left(\mathrm{NO}_{3}\right)_{3}, 0.1 \mathrm{~mL}$ of $1 \mathrm{M} \mathrm{CH}_{3} \mathrm{COOK}$ and $3.8 \mathrm{~mL}$ of ethanol. After incubation at $22{ }^{\circ} \mathrm{C}$ for $40 \mathrm{~min}$, the absorbance was measured at $415 \mathrm{~nm}$ against a blank consisting of solvent instead of sample using SPECTROstar Nano Microplate Reader (BMG LABTECH, Ortenberg, Germany). Quercetin was used as a standard in the linear range of 5-80 $\mu \mathrm{g} / \mathrm{mL}$ $\left(R^{2}=0.9972\right)$ and the results were expressed as $\mathrm{mg}$ quercetin equivalents $(\mathrm{QE}) / \mathrm{mL}$ juice.

\subsection{Total Monomeric Anthocyanin Content}

The total monomeric anthocyanin content was determined using the $\mathrm{pH}$ - differential method [50]. Properly diluted samples were mixed separately with $\mathrm{KCl}(0.025 \mathrm{M}, \mathrm{pH} 1.0)$ and $\mathrm{CH}_{3} \mathrm{COONa}(0.4 \mathrm{M}, \mathrm{pH} 4.5)$ in 1:4 ratio. The absorbance (A) was measured using SPECTROstar Nano Microplate Reader (BMG LABTECH, Ortenberg, Germany) at 520 and $700 \mathrm{~nm}$ after $15 \mathrm{~min}$ incubation at $22^{\circ} \mathrm{C}$ against a blank consisting of distilled water instead of sample, and the results were calculated as follows:

$$
\mathrm{A}=\left(\mathrm{A}_{520}-\mathrm{A}_{700}\right) \mathrm{pH} 1.0-\left(\mathrm{A}_{520}-\mathrm{A}_{700}\right) \mathrm{pH} 4.5
$$

The monomeric anthocyanin (MA) pigment concentration in the samples was calculated as:

$$
\text { Monomeric anthocyanin pigment }(\mathrm{mg} / \mathrm{L})=(\mathrm{A} \times \mathrm{MW} \times \mathrm{DF} \times 1000) /(\varepsilon \times 1)
$$

where $\mathrm{M}$ represents the molar mass of cyanidin-3-glycoside (449.2 g/M), DF is the dilution factor, $\varepsilon$ is the molar extinction coefficient $(26,900 \mathrm{~L} / \mathrm{M} \times \mathrm{cm})$, and 1 is the cuvette optical path length $(10 \mathrm{~mm})$. The final anthocyanin concentration of native or digested juice is expressed as $\mu$ g cyanidin-3-glucoside (C3GE)/L juice.

\subsection{Determination of Antioxidant Activity \\ 3.8.1. DPPH• Scavenging Activity}

The ability of the sample to donate an electron and scavenge DPPH radicals was determined by the slightly modified method of Brand-Williams et al. [51]. Freshly prepared $4 \times 10^{-4} \mathrm{M}$ solution of DPPH radicals was mixed with sample in a ratio of 2:0.5 $(v / v)$. The absorption was measured at $517 \mathrm{~nm}$ after $30 \mathrm{~min}$ incubation at $2{ }^{\circ} \mathrm{C}$ against a blank (distilled water). The absorbance of a control sample, a solution prepared in the same manner but with water instead of sample, was also measured using SPECTROstar Nano Microplate Reader (BMG LABTECH, Ortenberg, Germany). The DPPH radical scavenging activity of native or digested juice was presented as Trolox equivalents (TE) in the linear 
range of the standard $50-500 \mu \mathrm{M} / \mathrm{L}\left(R^{2}=0.9985\right)$ and expressed as $\mu \mathrm{M}$ TE per $\mathrm{mL}$ of juice $(\mu \mathrm{M} \mathrm{TE} / \mathrm{mL})$.

\subsection{2. $\mathrm{ABTS}^{\bullet+}$ Scavenging Activity}

The scavenging activity of the native or digested juice against $2,2^{\prime}$-azino-bis (3-ethylbenzothiazoline-6-sulfonic acid) radical action $\left(\right.$ ABTS $^{\bullet+}$ ) was estimated according to Re et al. [52]. Briefly, ABTS ${ }^{\bullet+}$ was produced by reacting ABTS stock solution (7 mM) with $2.45 \mathrm{mM}$ potassium persulfate and allowing the mixture to stand in the dark at at $22^{\circ} \mathrm{C}$ for $14 \mathrm{~h}$ before use. Afterward, the ABTS ${ }^{\bullet+}$ solution was diluted with ethanol to an absorbance of $0.7 \pm 0.02$ at $734 \mathrm{~nm}$ at $30^{\circ} \mathrm{C}$. Ten microlitres of native or digested juice was then mixed with $1.0 \mathrm{~mL}$ of diluted $\mathrm{ABTS}{ }^{\bullet+}$ solution, incubated at $30^{\circ} \mathrm{C}$ for $6 \mathrm{~min}$ and the absorbance was measured at the same temperature using SPECTROstar Nano Microplate Reader (BMG LABTECH, Ortenberg, Germany) against distilled water. The control sample consisted of a solution prepared in the same manner but with distilled water instead of sample. The results were expressed as Trolox equivalent antioxidant capacity (TEAC, $\mu \mathrm{M} \mathrm{TE} / \mathrm{mL})$ in the linear range of the standard 500-2000 $\mu \mathrm{M} / \mathrm{L}\left(R^{2}=0.9966\right)$.

\subsubsection{Ferric-Reducing Antioxidant Power}

The FRAP assay was carried out according to the procedure of Benzie and Strain [53] with slight modification. The FRAP reagent was prepared fresh daily by mixing acetate buffer (300 mM, pH 3.6), $10 \mathrm{mM}$ TPTZ (2,4,6-tri(2-pyridyl)-s-triazine) in $40 \mathrm{mM} \mathrm{HCl}$, and $20 \mathrm{mM} \mathrm{FeCl}_{3}$ at 10:1:1 (v/v/v) ratio and was warmed to $37^{\circ} \mathrm{C}$ prior to use. One hundred and fifty microliters of the native or digested juice were allowed to react with $2850 \mu \mathrm{L}$ of the FRAP reagent at $37^{\circ} \mathrm{C}$ for $4 \mathrm{~min}$. The absorbance was then recorded at $593 \mathrm{~nm}$ against a blank solution prepared in the same manner but with distilled water instead of sample using SPECTROstar Nano Microplate Reader (BMG LABTECH, Ortenberg, Germany) and the results were expressed as Trolox equivalents $(\mu \mathrm{M} \mathrm{TE} / \mathrm{mL})$ in the linear range of the standard 50-500 $\mu \mathrm{M} / \mathrm{L}\left(R^{2}=0.9970\right)$.

\subsubsection{Cupric Ion Reducing Antioxidant Capacity (CUPRAC) Assay}

The CUPRAC assay was carried out according to the procedure of Apak et al. [54]. One $\mathrm{mL}$ of $\mathrm{CuCl}_{2}$ solution $\left(1.0 \times 10^{-2} \mathrm{M}\right)$ was mixed with $1 \mathrm{~mL}$ of neo-cuproine methanolic solution $\left(7.5 \times 10^{-3} \mathrm{M}\right), 1 \mathrm{~mL}$ of ammonium-acetate buffer solution $(1 \mathrm{M}, \mathrm{pH} 7.0)$, and $0.1 \mathrm{~mL}$ of the native or digested juice followed by the addition of $1 \mathrm{~mL}$ distilled water (total volume $=4.1 \mathrm{~mL}$ ). The mixture was then vortexed for $10 \mathrm{sec}$ and incubated for $30 \mathrm{~min}$ at $22{ }^{\circ} \mathrm{C}$. The absorbance was measured at $450 \mathrm{~nm}$ against a blank solution prepared in the same manner but with distilled water instead of sample using SPECTROstar Nano Microplate Reader (BMG LABTECH, Ortenberg, Germany). Trolox was used as a standard in the linear range $200-2000 \mu \mathrm{M} / \mathrm{L}\left(R^{2}=0.9929\right)$ and the results were expressed as $\mu \mathrm{M} \mathrm{TE} / \mathrm{mL}$.

\subsection{Quantification of Phenolic Acids by HPLC-DAD}

HPLC analysis of the phenolic acids was performed on an Elite LaChrome (Hitachi, Tokyo, Japan) chromatograph equipped with a pump L-2100 (Hitachi, Tokyo, Japan), a column oven L-2350 (Hitachi, Tokyo, Japan) and diode array detector (DAD) L-2455 (Hitachi, Tokyo, Japan). HPLC separation was performed by using a column Supelco Discovery HS C18 ( $5 \mu \mathrm{m}, 250 \times 4.6 \mathrm{~mm}$, Sigma-Aldrich, St. Louis, MO, USA), operated at $30^{\circ} \mathrm{C}$ under gradient conditions with mobile phase consisting of $2 \%(v / v)$ acetic acid (solvent A) and acetonitrile (solvent B) as reported by Mihaylova et al. [55]. The samples were filtered thought a $0.45 \mu \mathrm{m}$ syringe filter (polytetrafluoroethylene filter) and $20 \mu \mathrm{L}$ were injected into the system. The gradient program used was: $0-1 \mathrm{~min}, 95 \% \mathrm{~A}$ and $5 \% \mathrm{~B}$; 1-40 min: 50\% A and 50\% B; 40-45 min: 100\% B; 46-50 min: 95\% A and 5\% B. The detection of chlorogenic, caffeic, $p$-coumaric, and sinapic acids was carried out at $320 \mathrm{~nm}$ in the linear range $10-100 \mu \mathrm{g} / \mathrm{mL}$ for all the standards. The corresponding correlation coefficients were 
$0.9986,0.9983,0.9900$, and 1.0000 , respectively. The identification was done by comparing the retention time of the compound and those of the corresponding standard. The flow rate was $0.8 \mathrm{~mL} / \mathrm{min}$. The results were expressed in $\mu \mathrm{g} / 100 \mathrm{~g}$ juice.

\subsection{Total Carbohydrate Contents}

The total sugar content of the juice samples and their digesta was estimated according to the phenol-sulfuric method [56]. Briefly, $0.1 \mathrm{~mL}$ of each sample was mixed with $1 \mathrm{~mL}$ of $5 \%$ phenol and $5 \mathrm{~mL}$ of sulfuric acid and placed in a water bath at $30{ }^{\circ} \mathrm{C}$ for $20 \mathrm{~min}$. The absorbance was measured at $490 \mathrm{~nm}$ against blank with ultra-purified water instead of juice using SPECTROstar Nano Microplate Reader (BMG LABTECH, Ortenberg, Germany). The amount of presenting carbohydrates was determined from the calibration curve using glucose as a standard in a linear range of 20 to $100 \mu \mathrm{g} / \mathrm{mL}\left(R^{2}=0.998\right)$ and the results were calculated as (g/100 g juice).

\subsection{Quantification of Sugars and Polyols by HPLC-RID Method}

The chromatographic separations and determination of sugars in the analyzed juices were performed on a high-performance liquid chromatograph HPLC Elite Chrome (Hitachi, Tokyo, Japan), equipped with a pump LC-20 AD, a column thermostat, refractive index detector (RID) Chromaster 5450 (Hitachi, Tokyo, Japan) and software. The separation was carried out on a Shode ${ }^{\circledR}$ Sugar SP0810 $(7 \mu \mathrm{m}, 300 \times 8.0 \mathrm{~mm}$ i.d., Tokyo, Japan $)$ column and a guard column Shodex SP -G $(5 \mu \mathrm{m}, 6 \times 50 \mathrm{~mm})$, operating at $85^{\circ} \mathrm{C}$, mobile phase $\mathrm{ddH}_{2} \mathrm{O}$ with flow rate $1.0 \mathrm{~mL} / \mathrm{min}$ and injection volume of $20 \mu \mathrm{L}$ as described by Petkova et al. [57]. The mobile phase was filtered under vacuum through a $0.2 \mu \mathrm{m}$ membrane filter (Sartorius AG, Goettingen, Germany). All samples before injection were filtered through ISOLAB (Eschau, Germany) filters with a diameter of $4 \mathrm{~mm}$ and a pore size of $0.45 \mu \mathrm{m}$. Only juices containing chokeberry fruits were analyzed on the same column at a flow rate of $0.5 \mathrm{~mL} / \mathrm{min}$, column temperature $80^{\circ} \mathrm{C}$ and RID operating temperature $35^{\circ} \mathrm{C}$ [58]. The detection of sucrose, glucose, fructose and sorbitol was performed in the linear range of $0.5-10 \mathrm{mg} / \mathrm{mL}$ (sucrose- $R^{2}=0.9996$, glucose $-R^{2}=0.9981$, fructose $-R^{2}=0.9994$, and sorbitol $\left.R^{2}=0.9995\right)$. The identification was done by comparing the retention time of the analytes with those of the corresponding standard. The results were calculated using peak area and the values were presented for $\mathrm{g} / 100 \mathrm{~g}$ juice.

\subsection{Bioaccessibility Measurement}

Bio-accessibility (\%) was defined as the content of the compound released in the simulated digestion process compared to the content of the compound in the sample, and the value was calculated according to the Equation (3) [59]:

$$
\text { Bio-accessibility }(\%)=\left(C_{\mathrm{f}} / \mathrm{C}_{0}\right) \times 100
$$

where $C_{f}$ is the final concentration of the compound (released in the simulated digestion) or activity and $\mathrm{C}_{0}$ is the initial concentration of the same compound or activity.

\subsection{Statistical Analysis}

All tests were carried out in triplicate and the results were presented as mean \pm standard deviation (SD) using Microsoft Excel 2010.

Each experiment was performed in triplicate. The mean values for TPC, TFC, Anthocyanins and antioxidant activity (AOA), measured by four different methods (DPPH, FRAP, ABTS, CUPRAC), were calculated prior and after digestion. The correlation coefficient between TPC, TFC, Anthocyanins and AOA was calculated at each phase of digestion. To test for similarities among fruit juices, principal component analysis (PCA) was applied to the data set through multivariate exploratory techniques using XLSTAT software version 2018.1 (Addinsoft SARL, Paris, France). In the present study, 14 variables (TPC, TFC, Anthocyanins and AOA at two different stages of digestion) on a 14-dimensional space were finally mapped to seven principal components. Maximum variability was covered 
through first two components (in the range $88-92 \%$ ) in all the analyses, which reflects that the outcome is produced without information loss.

\section{Conclusions}

The present study demonstrated that the studied fruit juices can be considered as a rich source of biologically active substances. In order to determine whether they remain active after passing through the digestive tract, the effect of in vitro digestion on the composition and content of sugars and phenolic substances was studied. The bioavailability of the tested compounds was affected by the digestive process and a significant decrease was reported. However, an exception to this trend was noted for some phenolic acids where liberation occurred in some digested samples. For all juices, total phenol content was found to contribute significantly to the AOA. Among them, pomegranate juice had the highest antioxidant activity, as well as the highest total content of phenols both before and after simulated digestion.

In conclusion, efforts should be put into juice stabilization prior to consumption in order to achieve better bio-accessibility of valuable compounds.

Author Contributions: Conceptualization, D.M. and I.D.; methodology, D.M. and I.D.; software, M.T.; validation, I.D. and M.T.; formal analysis, D.M. and I.D.; investigation, D.M., I.D., N.P., M.S.; resources, D.M.; data curation, I.D. and D.M.; writing—original draft preparation, D.M. and I.D.; writing-review and editing, D.M., I.D., N.P., M.S. and A.L.; visualization, D.M., I.D. and M.T.; supervision, D.M. and A.L.; project administration, D.M.; funding acquisition, A.L. All authors have read and agreed to the published version of the manuscript.

Funding: This research was funded by University of Food Technologies' Scientific Research Fund, project 03/19-H. The APC was funded by University of Padova-Department DAFNAE, Padova-Italy.

Institutional Review Board Statement: Not applicable.

Informed Consent Statement: Not applicable.

Data Availability Statement: The data presented in this study are available on request from the corresponding author.

Conflicts of Interest: The authors declare no conflict of interest.

Sample Availability: Not available.

\section{References}

1. Krinsky, N.I. Mechanism of action of biological antioxidants. Proc. Soc. Exp. Biol. Med. 1992, 200, 248-254. [CrossRef] [PubMed]

2. Amine, E.K.; Baba, N.H.; Belhadj, M.; Deurenberg-Yap, M.; Djazayery, A.; Forrestre, T.; Galuska, D.A.; Herman, S.; James, W.P.T.; M'Buyamba Kabangu, J.R.; et al. Diet, Nutrition and the Prevention of Chronic Diseases; World Health Organization Technical Report Series 916; WHO: Geneva, Switzerland, 2003. [CrossRef]

3. Patra, A.K. An Overview of Antimicrobial Properties of Different Classes of Phytochemicals. Diet. Phytochem. Microbes 2012, 1-32. [CrossRef]

4. Schreiner, M.; Huyskens-Keil, S. Phytochemicals in Fruit and Vegetables: Health Promotion and Postharvest Elicitors. CRC. Crit. Rev. Plant. Sci. 2006, 25, 267-278. [CrossRef]

5. Brodkorb, A.; Egger, L.; Alminger, M.; Alvito, P.; Assunção, R.; Ballance, S.; Bohn, T.; Bourlieu-Lacanal, C.; Boutrou, R.; Carrière, F.; et al. INFOGEST static in vitro simulation of gastrointestinal food digestion. Nat. Protoc. 2019, 14, 991-1014. [CrossRef] [PubMed]

6. Bohn, T.; Carriere, F.; Day, L.; Deglaire, A.; Egger, L.; Freitas, D.; Golding, M.; Le Feunteun, S.; Macierzanka, A.; Menard, O.; et al. Correlation between in vitro and in vivo data on food digestion. What can we predict with static in vitro digestion models? Crit. Rev. Food Sci. Nutr. 2018, 58, 2239-2261. [CrossRef] [PubMed]

7. Oliveira, A.; Pintado, M. Stability of polyphenols and carotenoids in strawberry and peach yoghurt throughout in vitro gastrointestinal digestion. Food Funct. 2015, 6, 1611-1619. [CrossRef]

8. Mosele, J.I.; Macià, A.; Romero, M.-P.; Motilva, M.-J. Stability and metabolism of Arbutus unedo bioactive compounds (phenolics and antioxidants) under in vitro digestion and colonic fermentation. Food Chem. 2016, 201, 120-130. [CrossRef] [PubMed]

9. Ozdal, T.; Capanoglu, E.; Altay, F. A review on protein-phenolic interactions and associated changes. Food Res. Int. 2013, 51, 954-970. [CrossRef]

10. Desseva, I.; Mihaylova, D. Influence of in vitro gastrointestinal digestion on phytochemicals in pomegranate juice. Food Sci. Technol. 2020, 40, 211-216. [CrossRef] 
11. Tagliazucchi, D.; Verzelloni, E.; Bertolini, D.; Conte, A. In vitro bio-accessibility and antioxidant activity of grape polyphenols. Food Chem. 2010, 120, 599-606. [CrossRef]

12. Bao, T.; Wang, Y.; Li, Y.-T.; Gowd, V.; Niu, X.-H.; Yang, H.-Y.; Chen, L.-S.; Chen, W.; Sun, C. Antioxidant and antidiabetic properties of tartary buckwheat rice flavonoids after in vitro digestion. J. Zhejiang Univ. Sci. B 2016, 17, 941-951. [CrossRef]

13. Desseva, I.; Stoyanova, M.; Petkova, N.; Mihaylova, D. Red beetroot juice phytochemicals bioaccessibility: An in vitro approach. Polish J. Food Nutr. Sci. 2020, 70, 45-53. [CrossRef]

14. Grgić, J.; Šelo, G.; Planinić, M.; Tišma, M.; Bucić-Kojić, A. Role of the Encapsulation in Bioavailability of Phenolic Compounds. Antioxidants. 2020, 9, 923. [CrossRef] [PubMed]

15. Zhang, Q.; Cheng, Z.; Wang, Y.; Fu, L. Dietary protein-phenolic interactions: Characterization, biochemical-physiological consequences, and potential food applications. Crit. Rev. Food Sci. Nutr. 2020, 1-27. [CrossRef]

16. Shahidi, F.; Peng, H. Bioaccessibility and bioavailability of phenolic compounds. J. Food Bioact. 2018, 4. [CrossRef]

17. Wootton-Beard, P.C.; Moran, A.; Ryan, L. Stability of the total antioxidant capacity and total polyphenol content of 23 commercially available vegetable juices before and after in vitro digestion measured by FRAP, DPPH, ABTS and Folin-Ciocalteu methods. Food Res. Int. 2011, 44, 217-224. [CrossRef]

18. Hallmann, E.; Orpel, E.; Rembiałkowska, E. The content of biologically active compounds in some fruits from natural state. Veg. Crop. Res. Bull. 2011, 75, 81-90. [CrossRef]

19. Adamenko, K.; Kawa-Rygielska, J.; Kucharska, A.; Piórecki, N. Characteristics of Biologically Active Compounds in Cornelian Cherry Meads. Molecules 2018, 23, 2024. [CrossRef]

20. Lachowicz, S.; Oszmiański, J. The influence of addition of cranberrybush juice to pear juice on chemical composition and antioxidant properties. J. Food Sci. Technol. 2018, 55, 3399-3407. [CrossRef]

21. Attri, S.; Singh, N.; Singh, T.R.; Goel, G. Effect of in vitro gastric and pancreatic digestion on antioxidant potential of fruit juices. Food Biosci. 2017, 17, 1-6. [CrossRef]

22. Tesoriere, L.; Allegra, M.; Butera, D.; Livrea, M.A. Absorption, excretion, and distribution of dietary antioxidant betalains in LDLs: Potential health effects of betalains in humans. Am. J. Clin. Nutr. 2004, 80, 941-945. [CrossRef]

23. Frank, T.; Stintzing, F.C.; Carle, R.; Bitsch, I.; Quaas, D.; Straß, G.; Bitsch, R.; Netzel, M. Urinary pharmacokinetics of betalains following consumption of red beet juice in healthy humans. Pharmacol. Res. 2005, 52, 290-297. [CrossRef]

24. Manach, C.; Williamson, G.; Morand, C.; Scalbert, A.; Rémésy, C. Bioavailability and bioefficacy of polyphenols in humans. I. Review of 97 bioavailability studies. Am. J. Clin. Nutr. 2005, 81, 230S-242S. [CrossRef] [PubMed]

25. Kay, C.D. Aspects of anthocyanin absorption, metabolism and pharmacokinetics in humans. Nutr. Res. Rev. 2006, 19, 137-146. [CrossRef] [PubMed]

26. Patel, A.R. Probiotic fruit and vegetable juices- recent advances and future perspective. Int. Food Res. J. 2017, $24,1850-1857$.

27. Choi, M.-H.; Kim, G.-H.; Park, K.-H.; Kim, Y.-S.; Shim, S.-M. Bioaccessibility of Total Sugars in Carbonated Beverages and Fermented Milks. J. Korean Soc. Appl. Biol. Chem. 2011, 54, 778-782. [CrossRef]

28. Oszmiański, J.; Lachowicz, S. Effect of the Production of Dried Fruits and Juice from Chokeberry (Aronia melanocarpa L.) on the Content and Antioxidative Activity of Bioactive Compounds. Molecules 2016, 21, 1098. [CrossRef]

29. Fejzić, A.; Ćavar, S. Phenolic Compounds and Antioxidant Activity of Some Citruses. Bull. Chem. Technol. Bosnia Herzegovina 2014, 42, 1-4.

30. Denev, P.N.; Kratchanov, C.G.; Ciz, M.; Lojek, A.; Kratchanova, M.G. Bioavailability and Antioxidant Activity of Black Chokeberry (Aronia melanocarpa) Polyphenols: In vitro and in vivo Evidence and Possible Mechanisms of Action: A Review. Compr. Rev. Food Sci. Food Saf. 2012, 11, 471-489. [CrossRef]

31. Denev, P.; Kratchanova, M.; Petrova, I.; Klisurova, D.; Georgiev, Y.; Ognyanov, M.; Yanakieva, I. Black Chokeberry (Aronia melanocarpa (Michx.) Elliot) Fruits and Functional Drinks Differ Significantly in Their Chemical Composition and Antioxidant Activity. J. Chem. 2018, 2018, 9574587. [CrossRef]

32. Wern, K.H.; Haron, H.; Keng, C.B. Comparison of total phenolic contents (TPC) and Antioxidant Activities of fresh fruit juices, commercial 100\% fruit juices and fruit drinks (Perbandingan jumlah kandungan fenolik (TPC) dan aktiviti antioksidan jus Buah-buahan segar, 100\% Jus Buah-buahan k. Sains Malays. 2016, 45, 1319-1327.

33. Campos-Vega, R.; Vázquez-Sánchez, K.; López-Barrera, D.; Loarca-Piña, G.; Mendoza-Díaz, S.; Oomah, B.D. Simulated gastrointestinal digestion and in vitro colonic fermentation of spent coffee (Coffea arabica L.): Bioaccessibility and intestinal permeability. Food Res. Int. 2015, 77, 156-161. [CrossRef]

34. Rodríguez-Roque, M.J.; Rojas-Graü, M.A.; Elez-Martínez, P.; Martín-Belloso, O. Changes in vitamin C, phenolic, and carotenoid profiles throughout in vitro gastrointestinal digestion of a blended fruit juice. J. Agric. Food Chem. 2013, 61, 1859-1867. [CrossRef]

35. Tenore, G.C.; Campiglia, P.; Ritieni, A.; Novellino, E. In vitro bioaccessibility, bioavailability and plasma protein interaction of polyphenols from Annurca apple (M. pumila Miller cv Annurca). Food Chem. 2013, 141, 3519-3524. [CrossRef]

36. Pandey, K.B.; Rizvi, S.I. Plant polyphenols as dietary antioxidants in human health and disease. Oxid. Med. Cell. Longev. 2009, 2, 270-278. [CrossRef] [PubMed]

37. Brglez Mojzer, E.; Knez Hrnčič, M.; Škerget, M.; Knez, Ž.; Bren, U. Polyphenols: Extraction Methods, Antioxidative Action, Bioavailability and Anticarcinogenic Effects. Molecules 2016, 21, 901. [CrossRef] [PubMed]

38. Coe, S.; Fraser, A.; Ryan, L. Polyphenol Bioaccessibility and Sugar Reducing Capacity of Black, Green, and White Teas. Int. J. Food Sci. 2013, 2013, 238216. [CrossRef] [PubMed] 
39. Bermudez-Soto, M.J.; Tomás-Barberán, F.A.; García-Conesa, M.T. Stability of polyphenols in chokeberry (Aronia melanocarpa) subjected to in vitro gastric and pancreatic digestion. Food Chem. 2007, 102, 865-874. [CrossRef]

40. Bouayed, J.; Deußer, H.; Hoffmann, L.; Bohn, T. Bioaccessible and dialysable polyphenols in selected apple varieties following in vitro digestion vs. their native patterns. Food Chem. 2012, 131, 1466-1472. [CrossRef]

41. Ovando-Martínez, M.; Gámez-Meza, N.; Molina-Domínguez, C.C.; Hayano-Kanashiro, C.; Medina-Juárez, L.A. Simulated Gastrointestinal Digestion, Bioaccessibility and Antioxidant Capacity of Polyphenols from Red Chiltepin (Capsicum annuum L. Var. glabriusculum) Grown in Northwest Mexico. Plant. Foods Hum. Nutr. 2018, 73, 116-121. [CrossRef]

42. Seraglio, S.K.T.; Valese, A.C.; Daguer, H.; Bergamo, G.; Azevedo, M.S.; Nehring, P.; Gonzaga, L.V.; Fett, R.; Costa, A.C.O. Effect of in vitro gastrointestinal digestion on the bioaccessibility of phenolic compounds, minerals, and antioxidant capacity of Mimosa scabrella Bentham honeydew honeys. Food Res. Int. 2017, 99, 670-678. [CrossRef] [PubMed]

43. Alminger, M.; Aura, A.-M.; Bohn, T.; Dufour, C.; El, S.N.; Gomes, A.; Karakaya, S.; Martínez-Cuesta, M.C.; McDougall, G.J.; Requena, T.; et al. In vitro Models for Studying Secondary Plant Metabolite Digestion and Bioaccessibility. Compr. Rev. Food Sci. Food Saf. 2014, 13, 413-436. [CrossRef] [PubMed]

44. Chen, G.-L.; Chen, S.-G.; Chen, F.; Xie, Y.-Q.; Han, M.-D.; Luo, C.-X.; Zhao, Y.-Y.; Gao, Y.-Q. Nutraceutical potential and antioxidant benefits of selected fruit seeds subjected to an in vitro digestion. J. Funct. Foods 2016, 20, 317-331. [CrossRef]

45. Haida, Z.; Hakiman, M. A comprehensive review on the determination of enzymatic assay and nonenzymatic antioxidant activities. Food Sci. Nutr. 2019, 7, 1555-1563. [CrossRef] [PubMed]

46. Ryan, L.; Prescott, S.L. Stability of the antioxidant capacity of twenty-five commercially available fruit juices subjected to an in vitro digestion. Int. J. Food Sci. Technol. 2010, 45, 1191-1197. [CrossRef]

47. McDougall, G.J.; Dobson, P.; Smith, P.; Blake, A.; Stewart, D. Assessing potential bioavailability of raspberry anthocyanins using an in vitro digestion system. J. Agric. Food Chem. 2005, 53, 5896-5904. [CrossRef] [PubMed]

48. Kujala, T.S.; Loponen, J.M.; Klika, K.D.; Pihlaja, K. Phenolics and betacyanins in red beetroot (Beta vulgaris) root: Distribution and effect of cold storage on the content of total phenolics and three individual compounds. J. Agric. Food Chem. 2000, 48, 5338-5342. [CrossRef] [PubMed]

49. Kivrak, İ.; Duru, M.E.; Öztürk, M.; Mercan, N.; Harmandar, M.; Topçu, G. Antioxidant, anticholinesterase and antimicrobial constituents from the essential oil and ethanol extract of Salvia potentillifolia. Food Chem. 2009, 116, 470-479. [CrossRef]

50. Lee, J.; Durst, R.; Wrolstad, R. AOAC 2005.02: Total Monomeric Anthocyanin Pigment Content of Fruit Juices, Beverages, Natural Colorants, and Wines- pH Differential Method. In Official Methods of Analysis of AOAC International; AOAC: Washington, DC, USA, 2005; pp. 37-39.

51. Brand-Williams, W.; Cuvelier, M.E.; Berset, C. Use of a free radical method to evaluate antioxidant activity. LWT-Food Sci. Technol. 1995, 28, 25-30. [CrossRef]

52. Re, R.; Pellegrini, N.; Proteggente, A.; Pannala, A.; Yang, M.; Rice-Evans, C. Antioxidant activity applying an improved ABTS radical cation decolorization assay. Free Radic. Biol. Med. 1999, 26, 1231-1237. [CrossRef]

53. Benzie, I.F.F.; Strain, J.J. [2] Ferric reducing/antioxidant power assay: Direct measure of total antioxidant activity of biological fluids and modified version for simultaneous measurement of total antioxidant power and ascorbic acid concentration. Methods Enzymol. 1999, 299, 15-27. [PubMed]

54. Apak, R.; Özyürek, M.; KarademirÇelik, S.; Güçlü, K. CUPRAC method 2004, JAFC 2013.

55. Mihaylova, D.; Vrancheva, R.; Desseva, I.; Ivanov, I.; Dincheva, I.; Popova, M.; Popova, A. Analysis of the GC-MS of volatile compounds and the phytochemical profile and antioxidant activities of some Bulgarian medicinal plants. Z. Naturforsch. C 2018, 74, 45-54. [CrossRef] [PubMed]

56. DuBois, M.; Gilles, K.A.; Hamilton, J.K.; Rebers, P.A.; Smith, F. Colorimetric Method for Determination of Sugars and Related Substances. Anal. Chem. 1956, 28, 350-356. [CrossRef]

57. Petkova, N.; Vrancheva, R.; Denev, P.; Ivanov, I.; Pavlov, A. HPLC-RID method for determination of inulin and fructooligosaccharides. Acta Sci. Nat. 2014, 1, 107.

58. Hadjikinova, R.; Petkova, N.; Hadjikinov, D.; Denev, P.; Hrusavov, D. Development and validation of HPLC-RID method for determination of sugars and polyols. J. Pharm. Sci. Res. 2017, 9, 1263-1269.

59. Leufroy, A.; Noël, L.; Beauchemin, D.; Guérin, T. Use of a continuous leaching method to assess the oral bioaccessibility of trace elements in seafood. Food Chem. 2012, 135, 623-633. [CrossRef] [PubMed] 